\title{
Articulating the Effect of Pesticides Use and Sustainable Develop- ment Goals (SDGs): The Science of Improving Lives through Deci- sion Impacts
}

\author{
Morufu Olalekan Raimi $^{1^{*}} \quad$ Tonye Vivien Odubo $^{2}$ Ogah Alima $^{3}$ Henry Akpojubaro Efeg- \\ bere $^{4}$ Abinotami Williams Ebuete ${ }^{2}$
}

1.Department of Community Medicine, Environmental Health Unit, Faculty of Clinical Sciences, Niger Delta University, Wilberforce Island, Bayelsa State, Nigeria.

2.Department of Geography and Environmental Management, Niger Delta University, Nigeria.

3.School of Health and Life Sciences, Teesside University, Middlesbrough, United Kingdom.

4.Department of Community Medicine, Edo University, Iyamho, Edo State, Nigeria.

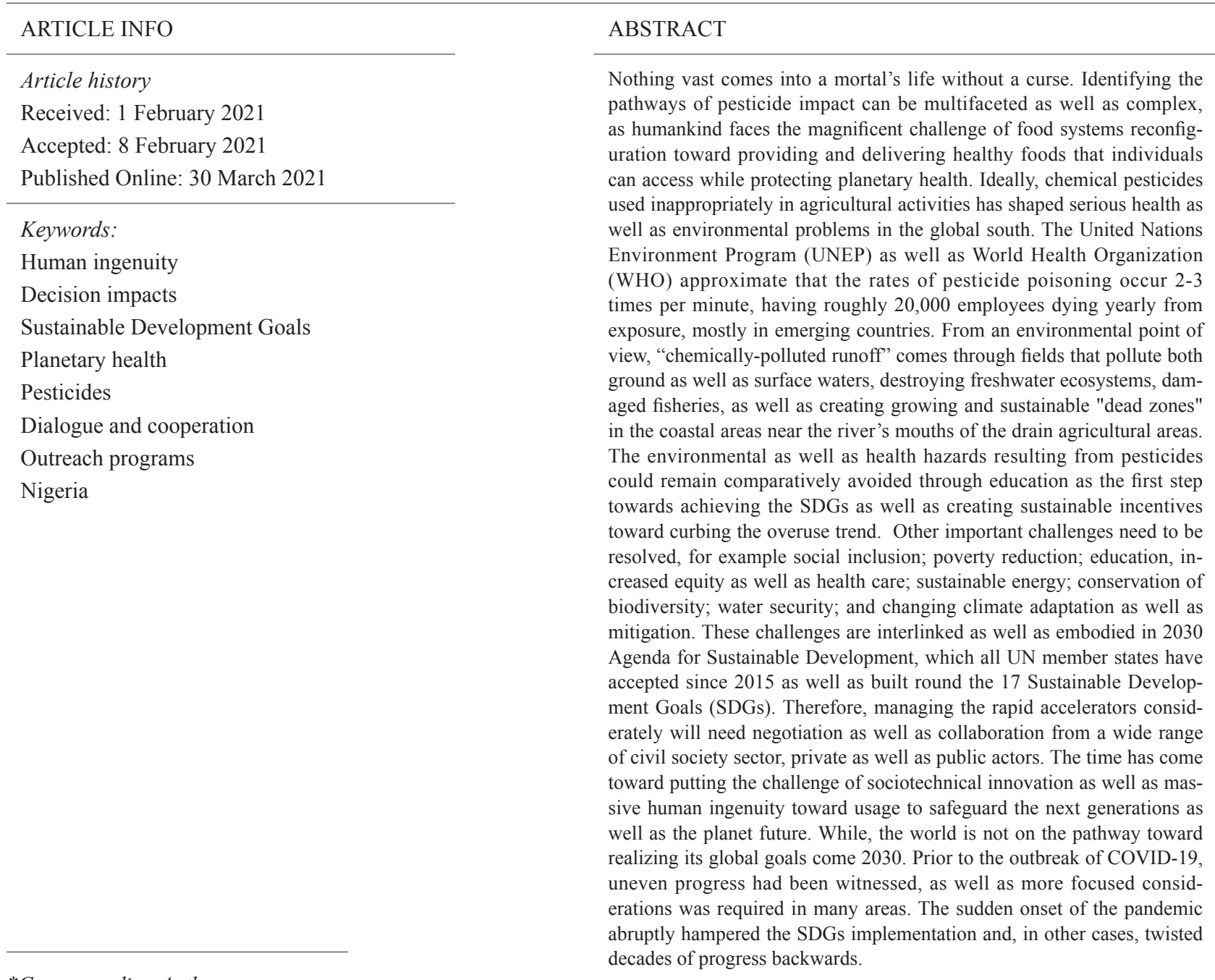

*Corresponding Author:

Morufu Olalekan Raimi;

ola07038053786@gmail.com; olamuf001@outlook.com; Alima2015@gmail.com 


\section{Introduction}

Just as the year 2020 mark entering of the Decade of Action toward delivering Sustainable Development Goals (SDGs), it is an important moment to spread the shared vision as well as quicken responses toward the world's momentous challenges by eradicating poverty as well as hunger due to changing climate (Raimi et al., 2018; Olalekan et al., 2020; Morufu et al., 2021). The outbreak of coronavirus disease pandemic (COVID-19) crisis is having an unprecedented disruptions toward global consumer supply chains markets, causing worldwide crude oil prices to drop and a turmoil in worldwide commodities as well as financial markets, wiping out sporting event as well as entertainment activities, shutting down of large swaths of individuals movements in various countries, as well as bans on intercontinental travel/ limitations through important air routes across globe and has triggered the largest recession in 90 years and set back hard earned development progress (Gift \& Olalekan, 2020; Gift et al., 2020; Samson et al., 2020; Raimi et al., 2020; Raimi $\&$ Raimi, 2020; Morufu et al., 2021). Unless we mobilize and equitably allocate resources for a large-scale, sustainable and sustained crisis response, the SDGs may well be beyond reach. As the outcomes have had a major impact on the livelihoods of households' as well as business activities, driven by global demand drop, resulting in consumer confidence as well as production slowdown.

The exceptional circumstances facing world events in 2020 , where we haven't had a lot of good news, require exceptional approaches, policy as well as decision making in all government spheres, as well as between private sectors and non-profit, remains progressively concentrated on supply chain as well as network issues which exceed governance, disciplinary as well as jurisdictional limits. While, globally, agricultural growth over the next decade is expected to ensure growing food demand as well as increase land competition. Agricultural land remains predictable to increase come 2030 with a decrease in population growth as well as crops continue to improve. Deforestation at present is on the decline and these activities are estimated to linger, particularly from 2030, while additional demand for agricultural land declines (Raimi et al., 2019; Olalekan et al., 2019; Raimi et al., 2019; Isah et al., 2020; Raimi et al., 2020; Morufu, 2021). There are remarkable developments in demographic differences between regions as well as countries. Come 2050, the population of the world is expected to increase from 2.2 billion individuals to around 9.2 billion. Much of this development will take place in the Middle East, South Asia as well as specifically Africa (see figure $1 \& 2$ below). Similarly, the population of Sub-Saharan Africa's is expected to increase over the next 30 years, growing by additional 1billion indi- viduals as well as kept on track toward overtaking central as well as south Asia, afterward as per the world's populous largest region. The south of the Sahara indicates high fertility rates meaning such Africa region account for above half of worldwide population growth at present and 2050, according to the United Nations Population Division projections report. The population in the regions will continue to grow towards the century end, as the number of individuals living in Asia as well as beyond decline. This trend reflects the situation in Nigeria, where the population at present surged from 95 million in 1990 to 210 million in 2020 (Olalekan et al., 2018; Olalekan et al., 2019; Olalekan et al., 2020). The population of Nigeria's will double by 400 million come 2050, then it will have surpassed the United States as the third largest inhabited country in the world. In Niger, where women have around seven children on average, the highest rate of birth in the world, the projected population almost triple to 66 million over the same time period. By 2050, Niger is projected to be the only single country in the world having a greater fertility level over a lifetime of four births per woman.

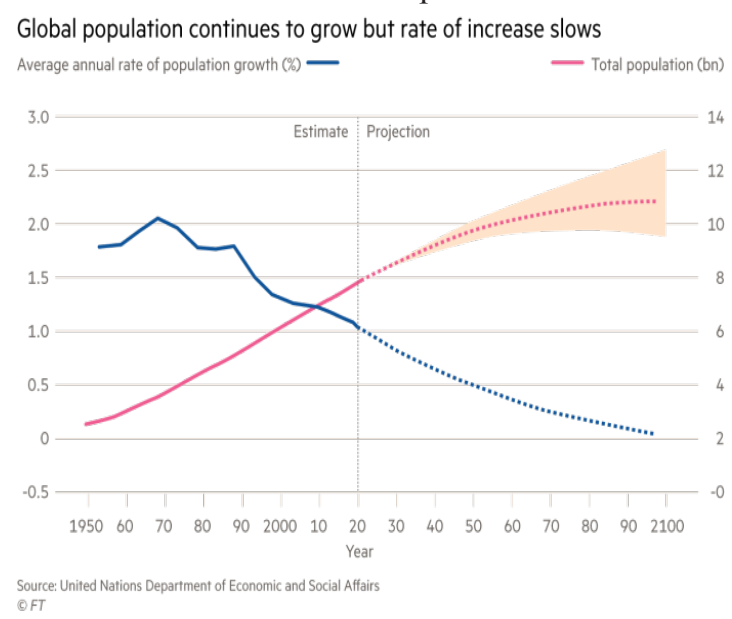

Figure 1. Global population continues to grow but rate of increase slows

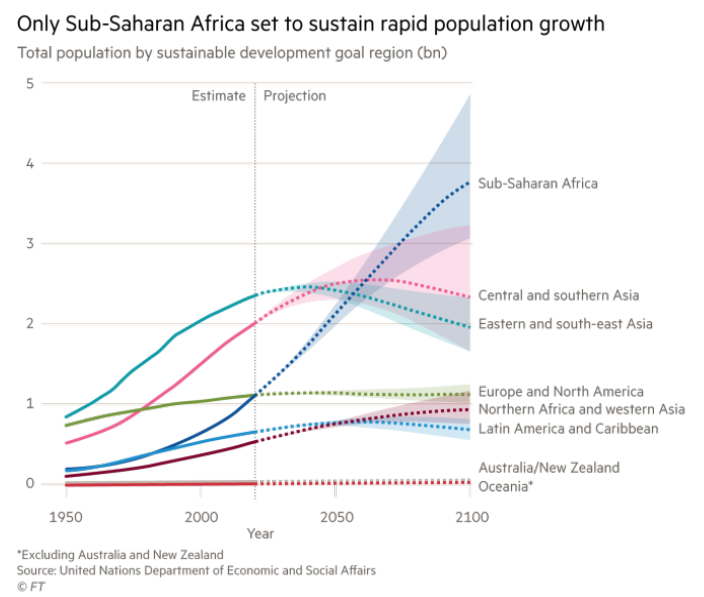

Figure 2. Only Sub-Saharan Africa set to sustain rapid population growth 


\section{Pesticide Use, Population And Sustainable Development}

The demographics profiles in every region are ageing, particularly in China, Italy as well as countries in the OECD. The populaces are becoming more and more urbanized. Come 2050, an additional 2.8 billion people are expected to live in cities more than today, or approximately $70 \%$ of the population of the world. Over the same period, rural population is expected to decline by 0.6 billion individuals. This rapid urban distribution is projected to spread disproportionately all over the globe. The urban population share in OECD countries are expected to reach $86 \%$ of the entire population come 2050 . In the global south, one of the smallest urban areas, the urban residents have reached almost $37 \%$ of the entire population in 2010, but some are expected to reach $60 \%$ come 2050 . Urban sprawl below 0.5 million populations is expected to grow faster when compared to other urban centers. This will remain a situational change resulting from observation in recent years, as large mega-cities continue to grow at a geometric rate (UN Habitat, 2006; United Nations, 2018). The prompt urbanization growth and industrialization has considerably contributed to pesticides promotion and usage, particularly in emerging countries, which have both the pros as well as cons, even though a population concentration could enable pesticides production as well as usage. As a result, it is often easier for pesticides exposure levels to be higher and could worsen environmental conditions in slums, with serious consequences for human health (Morufu et al., 2021; Morufu, 2021; Isah et al., 2020; Olalekan et al., 2020; Isah et al., 2020; Olalekan et al., 2020; Adedoyin et al., 2020; Olalekan et al., 2020; Sawyerr et al., 2018; Adeolu et al., 2018). Although demographics dynamics is a key driver of local as well as global environmental change. Population growth led to increased natural resources as well as land use consumption, posing additional environmental pressures. Variations in wealth as well as age structure likewise change lifestyle, consumption habits as well as diet, which may have a negative effect on the milieu. The population of the world have increased from below 4 billion in 1970 to 7 billion at the moment. Come 2050, the United Nations estimates the world population to be around 9.2 billion, or 2.2 billion additional individuals (see figure $1 \& 2$ above).

The population forecast discussed above indicate that the use of pesticides worldwide will increase and will basically stabilize by 2050 . Even though dietary variations remain likely to continue to remain a key factor for the growing agricultural demand production. While, 2015 symbolize a significant breakthrough towards the path to sustainable development. In line with the Millennium Development Goals, a novel cycle of Sustainable Development Goals (SDGs) aims toward guiding national governments as well as international community in their commitment toward achieving a sustainable world, particularly as human activities continue to push earth past its planetary boundaries, the need to accomplish the Sustainable Development Goals (SDGs) becomes more urgent than ever. With more than 800 million individuals remain at present starving, come 2050, worldwide production of food is expected to rise by $50 \%$ to feed above 9 billion individuals expected on the planet (Food and Agriculture Organization of the United Nations, 2018). The environmental, economic, as well as social issues of our world affect us all, from how we eat to how we work, how we communicate, and how we learn. There is a firmly believe that education is the first step towards achieving the SDGs. Collective learning and awareness through outreach improves and promotes the science and policies understanding behind sustainable development, and gives policy-makers, researchers, practitioners, and citizens to make informed decisions on how to support more sustainability through delivering courses covering all SDGs, including topics such as health, development, climate change, agriculture, human rights, and sustainable investment (Raimi et al., 2018; Raimi, 2019; Raimi et al., 2019; Omidiji and Raimi, 2019; Suleiman et al., 2019; Olalekan et al., 2019; Olalekan et al., 2020; Adedoyin et al., 2020; Olalekan et al., 2020; Raimi et al., 2020; Morufu et al., 2021). For several years, farmers in Nigerian have remained bedeviled through a cankerworm known as pesticides dependency as one and only veritable source toward increasing yield as well as become an albatross due in the direction of its effects on health. In spite of being miscomprehended as an expression of vulnerability in the face of blistering as well as dangerous times of strangulated economy, as concern around pesticides have become an issue due to the direct humans' actions. Adapting these procedures can remarkably decrease the exposure difficulties farmers faced. The foremost pesticides concerns are the long-term chronic exposure side effects for instance, the altered genetic stability of hormone balance, immune systems suppression as well as the capacity of some pesticides such as Cypermethrin (Raimi et al., 2020) to cause cancer and exposure to it causes toxic effects and it is carcinogenic to humans. Hospitals morbidity data shows that over 70 percent of rural residents who come to the hospitals for health care treatment suffer from typhoid, malaria, as well as other food and water-borne illnesses that the local authorities may perhaps remain empowered to address, prevent and accelerate actions toward 
fast-racking rural development, agricultural support and employment creation (Raimi et al., 2017; Olalekan et al., 2018; Raimi et al., 2019; Raimi, 2019; Raimi et al., 2019; Olalekan et al., 2019; Gift \& Olalekan, 2020; Olalekan et al., 2020; Gift et al., 2020). In addition, the identified practices by Nigerian farmers on the use of pesticides has been identified as a major obstacle toward eradicating food contamination which often leads to serious morbidity as well as loss of lives. The Federal Ministry of Science and Technology reported mid-year that more than 200,000 Nigerians die each year before, during and after planting from food-borne diseases and poisoning as a result of contamination. However, the success of the Millennium Development Goals (MDGs), nonetheless relatively distant from the ambitious goals set at the commencement of the millennium have prompted the world toward adopting a novel set of goals that build on these activities called the sustainable development goals (SDGs), this new set of goals aims amongst others put an to end to hunger as well as poverty come 2030. Like the Millennium Development Goals (MDGs), the Sustainable Development Goals (SDGs) are designed with evidence that through collaboration on a pre-agreed mission, the world has an advantage in meeting citizens aspirations, including farmers for prosperity, peace as well as progress. While, the sustainable development goals (SDGs) remain an assemblage of 17 global goals and 169 targets set through the United Nations General Assembly in 2015 for the year 2030 (see figure 3 below).

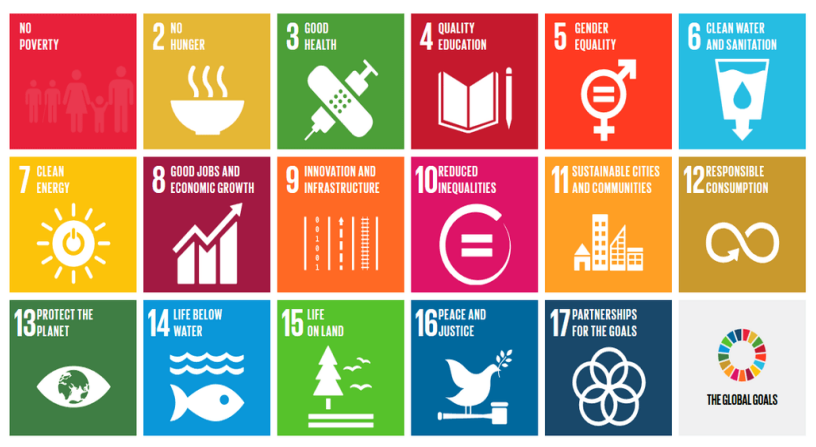

Figure 3. Source adapted from https://www.un.org/sustainabledevelopment/development-agenda/

The SDGs are part of the United Nation General Assembly resolution 70/1, the 2030 Agenda. The SDGs goals of No poverty, zero hunger etc. Agricultural development is an important nexus to the achievement of a good number of the SDGs and is a sound and most effective strategy to combat poverty (Goal 1), eradicate hunger (Goal 2), guarantee good health as well as wellbeing (Goal 3), promote industrial growth (Goal 9), reduce inequality (Goal 10 ) etc. The key objective of the sustainable development goals (SDGs) is to improve as well as promote the health and well-being of all farmers of all ages. Apparently, as a result of some accidental coincidence of sorts, farmer's profession whose role has conventionally remained toward producing food, has sequel toward a progression in scope over the years, in harmony toward depending on additional complex integration of the sustainable development goals (SDGs). The use of pesticides in farming practice speak to the importance the SDGs place on individuals, their health as well as general wellbeing, including responsible production and consumption. It recognises that pesticides are basically poisoning with a possibility toward wreaking untold harm as well as havoc on farmers, including posing danger to human lives and incomes of farmers as well as subject toward inconvenience and even additional pauperise farmers if the utmost affordable or cost-effective decisions are not conscientiously selected. Most importantly, it is particularly relevant that in the fight against pesticides, government must progressively play the important intercessor role for farmers. Very significantly, this is much in step with the SDGs which emphasise partnership as well as collective corporation towards the achievement of SDGs Goals and to intervene by sustaining efforts to reduce food contamination through collective learning and education of farmers. Also, there is need to embrace pro-private sector policies to improve agricultural practices of small holders' farmers and by extension, the relationship along the supply chain, increasing their outputs and sales of wholesome foods, as well as to improve the health of rural communities through consumption of safe products. The government need to work with the private sector to support and help stimulate industry innovations for sustainable argic food systems as well as producing better and safer food despite preserving biodiversity and natural resources. Also, empowered participation should be encouraged to opens up spaces for contestation as well as policies cooperation regarding pesticides usage. It is important to take the right decision as well as the right outcomes, and therefore for sustainable development. Growth must be propelled by agriculture prioritisation as a significant contributor toward the development as well as the rapid adoption of novel technologies toward boosting the sector as well as toward reshaping and improving the agriculture and food systems to better feed Nigerians and deliver sustainable development. There is need to be guided by our commitment to providing quality agricultural food systems as an essential tool for achieving a more peaceful, prosperous, and sustainable future. Moreover, "Eco-social policies" aim toward shifting behaviours or providing motivations for additional and advanced sustainable environmental 
management or use of resource, while strengthening the adaptive capacities or resilience of communities as well as individuals, hence accomplishing social goals.

\section{The Way Forward}

Indeed, everyone must work together to achieve the 2030 Agenda for Sustainable Development and Sustainable Development Goals (SDGs). Different sectors as well as actors will need to work collectively in a cohesive manner through merging resources, knowledge as well as expertise. Hence, there is a need for innovative and sectorial multistakeholder collaboration, which is an important key to getting us toward where we need to be in 2030 . More than ever, partnerships should continue toward supporting government led activities to achieve sustainable development. Unlocking the immense knowledge as well as experience that these corporations as well as partners collaboratively possess, grips the vital toward efficiently supporting Sustainable Development Goals (SDGs) implementation. The Agenda of the 2030 will necessitate an increased teamwork among all organizations, all States as well as all individuals, so that we can magnificently deliver on the promises of achieving and fulfilling the 17 interconnected Sustainable Development Goals (SDGs). The voyage toward achieving and fulfilling all the 17 Sustainable Development Goals as well as accomplishing a better future for all individuals, which is together filled through opportunity as well as great challenge. It is a problem that is facing all individuals as well as all nations. Nonetheless this problem could be overcome through collaboration in a real-time partnership to design critical as well as outreach programs that are targeted, which address precisely pesticide risk, safe handling as well as forestalling behavior which are critical characteristics aimed at promoting planetary and human health that we all desire. At the same time, investment in the SDGs reduces exposure and vulnerability and is a major driver of resilience. While all actors must understand, manage and ultimately reduce pesticide risks, governments must lead in taking a risk-informed perspective. First, governments are the "risk-bearer of last resort". When a crisis occurs, private risks often become public liabilities. Thus, policymakers need to mainstream risk considerations in all policies, processes and decisions.

Going forward, there is need to invest in a sustainable, resilient and equitable recovery of safe pesticide use. Rather than trying to restore yesterday's economy, governments must invest in measures to protect their citizens from pesticide risk, poverty (forecasts designate that the pandemic might likely push 71 million individuals back into extreme poverty by 2020 , in what would remain the first global poverty rise since 1998. Several of these individuals are informal economy employees, whose earnings dropped through $60 \%$ in the first calendar month of the disaster. Half of the global employees of about 1.6 billion individuals supporting themselves as well as their families through uncertain as well as frequently unsafe jobs within the informal economy, as well as having been remarkably affected), hunger and existential threats, while sharing the fruits of globalization more equally. New forms of financing, including longer-term instruments spanning 40 - 50 years, may be needed for these investments. Investment alone, however, is not enough. To address the systemic nature of global pesticide risks, there is need to reform our agricultural institutions and policy architecture, strengthen multilateralism, and create new platforms and networks for global cooperation. These views will inform discussions within the United Nations, government and with other partners in 2021 and going forward. It is urged that all governments and other stakeholders to meet the expectations of the citizen they serve with unity, solidarity and coordinated multilateral action. The view underlines the need for policy actions toward ensuring effective support until the recovery is firmly underway.

\section{Competing Interests}

We declare that we have no conflict of interest that could be perceived as prejudicing the impartiality of the research reported. This research received no specific grant from any funding agency in the public, commercial, or not-for-profit sectors.

\section{References}

[1] Adedoyin OO, Olalekan RM, Olawale SH, et al (2020). A review of environmental, social and health impact assessment (Eshia) practice in Nigeria: a panacea for sustainable development and decision making. MOJ Public Health. 2020;9(3):81-87. DOI: 10.15406/mojph.2020.09.00328. https://medcraveonline.com/MOJPH/MOJPH-09-00328.pdf.

[2] Adeolu T., Odipe O. E. and Raimi M. O. (2018). Practices and Knowledge of Household Residents to Lead Exposure in Indoor Environment in Ibadan, Oyo State, Nigeria. Journal of Scientific Research \& Reports 19(6): 1-10, 2018; Article NO. JSRR.43133 ISSN: 2320-0227.

[3] Food and Agriculture Organization of the United Nations (2018). Future of food and agriculture 2018: alternative pathways to 2050. 2018. http://www.fao. org/3/CA1553EN/ca1553en.pdf (accessed Sept 24, 2020).

[4] Gift RA, Olalekan RM, Owobi OE, Oluwakemi RM, 
Anu B, Funmilayo AA (2020). Nigerians crying for availability of electricity and water: a key driver to life coping measures for deepening stay at home inclusion to slow covid-19 spread. Open Access Journal of Science. 2020;4(3):69-80. DOI: 10.15406/ oajs.2020.04.00155.

[5] Gift R A, Olalekan RM (2020). Access to electricity and water in Nigeria: a panacea to slow the spread of Covid-19. Open Access J Sci. 2020;4(2):34. DOI: 10.15406/oajs.2020.04.00148. https://medcrave.com/ index.php?/articles/det/21409/https://www.un.org/ sustainabledevelopment/development-agenda/

[6] Isah, H. M., Sawyerr, H. O., Raimi, M. O., Bashir, B. G., Haladu, S. \& Odipe, O. E. (2020). Assessment of Commonly Used Pesticides and Frequency of Self-Reported Symptoms on Farmers Health in Kura, Kano State, Nigeria. Journal of Education and Learning Management (JELM), HolyKnight, vol. 1, 31-54. doi.org/10.46410/jelm.2020.1.1.05. https:// holyknight.co.uk/journals/jelm-articles/.

[7] Isah Hussain Muhammad, Raimi Morufu Olalekan, Sawyerr Henry Olawale, Odipe Oluwaseun Emmanuel, Bashir Bala Getso, Suleiman Haladu (2020) Qualitative Adverse Health Experience Associated with Pesticides Usage among Farmers from Kura, Kano State, Nigeria. Merit Research Journal of Medicine and Medical Sciences (ISSN: 2354-323X) Vol. 8 (8) pp. 432-447, August, 2020. DOI: 10.5281/zenodo.4008682. https://meritresearchjournals.org/mms/ content/2020/August/Isah\%20et\%20al.htm.

[8] Morufu Olalekan Raimi, Ebikapaye Okoyen, Tuebi Moses, Aziba-anyam Gift Raimi, Adedoyin Oluwatoyin Omidiji, Aishat Funmilayo Abdulraheem, Mariam Oluwakemi Raimi, Beatrice Oka Joseph (2021) Do Weak Institutions Prolong Crises? [\#ENDSARs] in the Light of the Challenges and opportunities beyond COVID-19 Pandemic and the Next Normal in Nigeria. Communication, Society and Media. ISSN 2576-5388 (Print) ISSN 2576-5396 (Online) Vol. 4, No. 2, DOI: https://doi.org/10.22158/csm.v4n2p1. http://www.scholink.org/ojs/index.php/csm/article/ view/3790.

[9] Morufu Olalekan Raimi, Tonye Vivien Odubo \& Adedoyin Oluwatoyin Omidiji (2021) Creating the Healthiest Nation: Climate Change and Environmental Health Impacts in Nigeria: A Narrative Review. Scholink Sustainability in Environment. ISSN 2470637X (Print) ISSN 2470-6388 (Online) Vol. 6, No. 1, 2021 www.scholink.org/ojs/index.php/se. URL: http://dx.doi.org/10.22158/se.v6n1p61.

http://www.scholink.org/ojs/index.php/se/article/ view/3684
[10] Morufu Olalekan Raimi (2021). "Self-reported Symptoms on Farmers Health and Commonly Used Pesticides Related to Exposure in Kura, Kano State, Nigeria". Annals of Community Medicine \& Public Health. 1(1): 1002. http://www.remedypublications. com/open-access/self-reported-symptoms-on-farmers-health-and-commonly-used-pesticides-related-6595.pdf. http://www.remedypublications.com/annals-of-community-medicine-public-health-home.php.

[11] Olalekan RM, Muhammad IH, Okoronkwo UL, Akopjubaro EH (2020). Assessment of safety practices and farmer's behaviors adopted when handling pesticides in rural Kano state, Nigeria. Arts \& Humanities Open Access Journal. 2020;4(5):191-201. DOI: 10.15406/ahoaj.2020.04.00170.

[12] Olalekan R. M, Dodeye E. O, Efegbere H. A, Odipe O. E. Deinkuro N. S, Babatunde A and Ochayi E. O (2020) Leaving No One Behind? Drinking-Water Challenge on the Rise in Niger Delta Region of Nigeria: A Review. Merit Research Journal of Environmental Science and Toxicology (ISSN: 2350-2266) Vol. 6(1): 031-049 DOI: 10.5281/zenodo.3779288.

[13] Olalekan RM, Oluwatoyin OA, Olawale SH, Emmanuel OO, Olalekan AZ (2020) A Critical Review of Health Impact Assessment: Towards Strengthening the Knowledge of Decision Makers Understand Sustainable Development Goals in the Twenty-First Century: Necessity Today; Essentiality Tomorrow. Research and Advances: Environmental Sciences. 2020(1): 72-84. DOI: 10.33513/RAES/2001-13. https://ospopac.com/journal/environmental-sciences/ early-online.

[14] Olalekan R. M, Oluwatoyin O and Olalekan A (2020) Health Impact Assessment: A tool to Advance the Knowledge of Policy Makers Understand Sustainable Development Goals: A Review. ES Journal of Public Health; 1(1); 1002. https://escientificlibrary.com/public-health/in-press.php.

[15] Olalekan RM (2020). "What we learn today is how we behave tomorrow": a study on satisfaction level and implementation of environmental health ethics in Nigeria institutions. Open Access Journal of Science; 4(3):82-92. DOI: 10.15406/oajs.2020.04.00156.

[16] Olalekan RM, Adedoyin OO, Ayibatonbira A, et al (2019). "Digging deeper" evidence on water crisis and its solution in Nigeria for Bayelsa state: a study of current scenario. International Journal of Hydrology. 2019;3(4):244-257. DOI: 10.15406/ ijh.2019.03.00187.

[17] Olalekan RM, Omidiji AO, Williams EA, Christianah MB, Modupe O (2019). The roles of all tiers of government and development partners in envi- 
ronmental conservation of natural resource: a case study in Nigeria. MOJ Ecology \& Environmental Sciences 2019;4(3):114-121. DOI: 10.15406/ mojes.2019.04.00142.

[18] Olalekan R. M, Vivien O. T, Adedoyin O. O, et al. (2018). The sources of water supply, sanitation facilities and hygiene practices in oil producing communities in central senatorial district of Bayelsa state, Nigeria. MOJ Public Health. 2018;7(6):337-345. DOI: 10.15406/mojph.2018.07.00265.

[19] Omidiji A. O and Raimi M. O (2019) Practitioners Perspective of Environmental, Social and Health Impact Assessment (ESHIA) Practice in Nigeria: A Vital Instrument for Sustainable Development. Paper Presented at the Association for Environmental Impact Assessment of Nigeria (AEIAN) On Impact Assessment: A Tool for Achieving the Sustainable Development Goals in Nigeria, 7th and 8th November, 2019 In University of Port Harcourt. https:// aeian.org/wp-content/uploads/2019/08/EIA-Presentations-Portharcourt.pdf.

[20] Raimi Morufu Olalekan \& Raimi Aziba-anyam Gift (2020). The Toughest Triage in Decision Impacts: Rethinking Scientific Evidence for Environmental and Human Health Action in the Times of Concomitant Global Crises. CPQ Medicine, 11(1), 01-05.

[21] Raimi Morufu Olalekan, Moses Tuebi, Okoyen Ebikapaye, Sawyerr Henry Olawale, Joseph Beatrice Oka, Oyinlola Bilewu Olaolu (2020) "A Beacon for Dark Times: Rethinking Scientific Evidence for Environmental and Public Health Action in the Coronavirus Diseases 2019 Era" Medical and Research Microbiology, Vol. 1, Issues 3.

[22] Raimi Morufu Olalekan, Ihuoma Blossom Adindu, Esther Onyinyechi Udensin, Abdulraheem Aishat Funmilayo, Opufou Tarekebi, Deinkuro Nimisingha Sanchez, Adebayo Patrick Adekunle and Adeniji Anthony Olusola (2020) "Health Impact Assessment: Expanding Public Policy Tools for Promoting Sustainable Development Goals (SDGs) in Nigeria”. EC Emergency Medicine and Critical Care 4.9 (2020).

[23] Raimi Morufu Olalekan, Sawyerr Henry Olawale and Isah Hussain Muhammad (2020) Health risk exposure to cypermethrin: A case study of kano state, Nigeria. Journal of Agriculture. 7th International Conference on Public Healthcare and Epidemiology. September 14-15, 2020 | Tokyo, Japan.

[24] Raimi M. O, Omidiji A. O, Adio Z. O (2019) Health Impact Assessment: A Tool to Advance the Knowledge of Policy Makers Understand Sustainable Development Goals. Conference paper presented at the: Association for Environmental Impact Assessment of
Nigeria (AEIAN) On Impact Assessment: A Tool for Achieving the Sustainable Development Goals in Nigeria, 7th and 8th November, 2019 in University of Port Harcourt. DOI: 10.13140/RG.2.2.35999.51366 https://www.researchgate.net/publication/337146101.

[25] Raimi Morufu Olalekan., Oluwaseun Emmanuel Odipe, Nimisingha Deinkuro Sanchez, Abdulraheem Aishat Funmilayo, Okolosi-Patainnocent Edewor, Habeeb Modupe Lateefat1 and Mary Fadeyibi (2019) Assessment of Environmental Sanitation, Food Safety Knowledge, Handling Practice among Food Handlers of Bukateria Complexes in Iju Town, Akure North of Ondo-State, Nigeria. Acta Scientific Nutritional Health 3.6 (2019): 186-200. DOI: 10.31080/ ASNH.2019.03.0308.

[26] Raimi M. O, Abdulraheem A. F, Major Iteimowei, Odipe O. E, Isa H. M, Onyeche Chinwendu (2019). The Sources of Water Supply, Sanitation Facilities and Hygiene Practices in an Island Community: Amassoma, Bayelsa State, Nigeria. Public Health Open Access 2019, 3(1): 000134. ISSN: 2578-5001. DOI: $10.23880 /$ phoa-16000134.

[27] Raimi Morufu Olalekan (2019) 21st Century Emerging Issues in Pollution Control. 6th Global Summit and Expo on Pollution Control May 06-07, 2019 Amsterdam, Netherlands.

[28] Raimi M. O, Bilewu O. O, Adio Z. O, Abdulrahman H (2019) Women Contributions to Sustainable Environments in Nigeria. Journal of Scientific Research in Allied Sciences. 5(4), 35-51. ISSN NO. 2455-5800. DOI No. 10.26838/JUSRES.2019.5.4.104.

[29] Raimi M O, Suleiman R M, Odipe O E, Salami J T, Oshatunberu M, et al (2019). Women Role in Environmental Conservation and Development in Nigeria. Ecology \& Conservation Science; 1(2): DOI: 10.19080/ECOA.2019.01.555558. Volume 1 Issue 2 - July 2019. https://juniperpublishers.com/ecoa/pdf/ ECOA.MS.ID.555558.pdf

[30] Raimi Morufu Olalekan, Tonye V. Odubo, Omidiji Adedoyin O, Oluwaseun E. Odipe (2018) Environmental Health and Climate Change in Nigeria. World Congress on Global Warming. Valencia, Spain. December 06-07, 2018.

[31] Raimi, M. O, Pigha, Tarilayun K and Ochayi, E. O (2017) Water-Related Problems and Health Conditions in the Oil Producing Communities in Central Senatorial District of Bayelsa State. Imperial Journal of Interdisciplinary Research (IJIR) Vol-3, Issue-6, ISSN: 2454-1362.

[32] Samson T.K., Ogunlaran O.M., Raimi O.M (2020); A Predictive Model for Confirmed Cases of COVID-19 in Nigeria. European Journal of Applied Sciences, 
Volume 8, No 4, Aug 2020;pp:1-10. DOI: 10.14738/ aivp.84.8705. DOI: https://doi.org/10.14738/ aivp.84.8705.

[33] Sawyerr O. H, Odipe O. E, Olalekan R. M, et al. (2018) Assessment of cyanide and some heavy metals concentration in consumable cassava flour "lafun" across Osogbo metropolis, Nigeria. MOJ Eco Environ Sci. 2018;3(6):369-372. DOI: 10.15406/ mojes.2018.03.00115.

[34] Suleiman Romoke Monsurat, Raimi Morufu Olalekan and Sawyerr Henry Olawale (2019) A Deep Dive into the Review of National Environmental Standards and Regulations Enforcement Agency (NESREA) Act. International Research Journal of Applied Sciences. pISSN: 2663-5577, eISSN: 2663-5585. DOI No. Irjas.2019.123.123. www.scirange.com. https://scirange.com/abstract/irjas.2019.108.125.
[35] United Nations (2018). World Urbanization Prospects: The 2018 Revision. Key Facts. Technical report, United Nations.

[36] UN (2011), World Population Prospects: The 2010 Revision, New York.

[37] UN (2010), World Urbanization Prospects: The 2009 Revision, UN Habitat, New York.

[38] UN (United Nations) (2009), World Population Prospects: The 2008 Revision, New York.

[39] UN Habitat (2006), State of the World's Cities: 2006/2007, UN Habitat, New York.

[40] UN Habitat (2003), The Challenge of Slums: Global Report on Human Settlements 2003, UN Habitat, New York.

[41] World Bank (2010), World Development Indicators, World Bank, Washington, DC, http://data.worldbank. org/data-catalog/world-development-indicators. 